\title{
Metodologia badań postaw politycznych młodzieży w świetle badań empirycznych
} Methodology of political attitudes research towards empirical studies

Stowa kluczowe: młodzież, metodologia badań, badania empiryczne

Keywords: youth, survey methodology, emipirical research

\begin{abstract}
Abstrakt: Artykut stanowi próbe uzupetnienia dyskusji metodologicznych o problematykę związana z udziałem młodzieży $w$ badaniach spotecznych. Celem artykutu jest analiza, wskazanie cech $i$ etapów procesu badawczego, metod $i$ zakresu badań $w$ kontekście dostepnych badan dotyczacych partycypacji politycznej młodych Polaków. Przedmiotem analizy jest także zrealizowany we wrześniu 2019 r. projekt badawczy „Determinanty partycypacji wyborczej młodych Polaków w 2019 r.”.
\end{abstract}

Abstract: The article complements the methodological discussions with issues related to the participation of young people in social research. The scientific purpose of the article is to analyze, indicate the features and stages of the research process, methods and scope of research in the context of available research on the political participation of young Poles. The subject of the analysis is also the research project "Determinants of the electoral participation of young Poles in 2019” carried out in September 2019.

* ORCID ID: https://orcid.org/0000-0003-4897-8393, politolog, doktorant Wydziału Nauk Politycznych i Studiów Międzynarodowych Uniwersytetu Warszawskiego, stypendysta rektora Uniwersytetu Warszawskiego, Fundacji Konrada Adenauera i DAAD Polska. Kierownik realizowanego z Fundacją Konrada Adenauera w Polsce i Centrum Badań Marketingowych „INDICATOR” projektu badawczego „Determinanty partycypacji wyborczej młodych Polaków w 2019 r.”. E-mail: adamkadziela93@gmail.com 


\section{Wprowadzenie}

O tym jak istotne jest poznanie postaw politycznych młodzieży świadczy fakt, że jest to zdolna do zmiany wyników wyborów grupa społeczna, która w porównaniu do ogółu populacji rzadziej bierze udział w wyborach, w mniejszym stopniu wykazuje zaangażowanie i zainteresowanie życiem politycznym. Przynajmniej tak było do 2020 r. - roku, w którym w przeprowadzonych wyborach prezydenckich, jak wynika z badań exit poll Ipsos, wzięło udział ponad 60\% młodych Polaków w wieku od 18. do 29. roku życia. W I turze frekwencja wśród najmłodszych wyborców wyniosła $62,3 \%$ i była zaledwie o 0,6 p.p. niższa od frekwencji wśród wszystkich Polaków uprawnionych do głosowania. W II turze frekwencja wśród młodych wzrosła o blisko 5 p.p. do poziomu 67,2\% i była o 1,7 p.p. niższa od tej, którą odnotowano wśród wszystkich uprawnionych do głosowania. To niewątpliwie pozytywna zmiana w stosunku do poziomu frekwencji w wyborach do Parlamentu Europejskiego oraz w wyborach parlamentarnych, które odbyły się w 2019 r. W tych pierwszych do urn poszło zaledwie 27,6\% (wobec 45,7\% frekwencji wśród wszystkich wyborców), zaś w wyborach do Sejmu i Senatu udział wzięło 46,4\% młodych Polaków uprawnionych do głosowania (wobec frekwencji na poziomie $61,7 \%$ w ogóle społeczeństwa). W tym miejscu mogą pojawić się słuszne zarzuty, że frekwencja w wyborach prezydenckich w Polsce zazwyczaj jest wyższa od tej, którą odnotowuje się w innego rodzaju wyborach. Warto więc potwierdzić przekonanie o wyjątkowości wyborów prezydenckich, które odbyły się w 2020 r., dokonując porównania z frekwencją w tej samej grupie wiekowej wyborców w wyborach prezydenckich w 2015 r. Wówczas w I turze wyborów do urn wyborczych poszło 46,1\% osób w wieku 18-29 lat tj. mniej o 16,3 p.p. niż w I turze w 2020 r. i o 2,86 p.p. mniej niż wśród ogółu osób uprawnionych do głosowania.

Przemiany polityczne, społeczne i gospodarcze po 1989 r. zaowocowały stopniowym wzrostem dobrobytu Polaków, poziomu wykształcenia, a także utrwalaniem systemu demokratycznego. Ten ostatni czynnik warunkowany jest m.in. postawami obywateli i wynikającą z owych postaw kulturą polityczną. W niniejszej pracy wiodącym tematem będą postawy polityczne młodzieży oraz badania poświęcone tej problematyce. Temat jest szczególnie istotny także ze względu na fakt, że to w latach młodości kształtują się postawy i preferencje polityczne obywateli. W'śród czynników wpływających na postawy młodych Polaków należy wyróżnić m.in. wiek, płeć, wykształcenie, sytuację ekonomiczną. W artykule zaprezentowane zostały dane potwierdzające powyższe tezy. Liczebność tej grupy społecz- 
nej i idący za tym potencjał powoduje, że postawy polityczne młodzieży winny być przedmiotem analiz badaczy i uczestników życia publicznego. Poznawanie rzeczywistości, a także jej przekształcenie zgodne z potrzebami człowieka, wymaga posiadania o niej wiedzy zawierajacej również informacje liczbowe. Informacje takie możemy otrzymać albo badając bezpośrednio systemy empiryczne tworzace otaczająca nas rzeczywistość materialna, albo zastęując badania tych systemów badaniami ich materialnych lub abstrakcyjnych modeli ${ }^{1}$ - wskazywał w prof. Stanisław Pabis w swojej publikacji „Metodologia i metody nauk empirycznych”. W tak zdefiniowanym podejściu metodologicznym, określenie postaw politycznych młodzieży będzie ściśle powiązane $\mathrm{z}$ analizą metod i zakresu dostępnych badań postaw politycznych młodzieży. Obraz dotyczący postaw politycznych młodych Polaków odzwierciedlać będą dane związane z frekwencją wyborczą, członkostwem $\mathrm{w}$ organizacjach politycznych, a także badaniami realizowanymi przez ośrodki badawcze. W artykule punktem wyjścia do analizy metodologii badań postaw politycznych młodych Polaków są dane z dostępnych w literaturze przedmiotu badań, a także dane $\mathrm{z}$ autorskiego badania przeprowadzonego metodą wywiadów telefonicznych ze wspomaganiem komputerowym (CATI), na reprezentatywnej, ogólnopolskiej grupie pełnoletnich mieszkańców Polski do 30. roku życia. W dniach 5-23 września 2019 r. Centrum Badań Marketingowych INDICATOR zrealizowało je na zlecenie Fundacji Konrada Adenauera w Polsce ( $\mathrm{N}=1200$ wywiadów).

\section{Postawy polityczne młodzieży w Polsce w świetle dostępnych badań empirycznych}

Problematyka postaw politycznych młodzieży, mimo iż stale jest obecna w debacie publicznej, nie była w Polsce przedmiotem wielu badań empirycznych. Analiza literatury przedmiotu wskazuje, że najczęściej prezentowane są dane ilościowe, dotyczące frekwencji wyborczej i preferencji wyborczych młodych Polaków. Jednakże przegląd dostępnych badań pozwala na wysnucie wniosku, że brak jest dostępnych badań na ogólnopolskiej grupie młodych Polaków, których przedmiotem byłyby ich postawy. Niewiele z dostępnych opracowań ma też charakter jakościowy i stara się odpowiedzieć na pytania o przyczyny występowania określonych postaw wśród młodzieży. Przed przejściem do szczegółowej analizy tematu oraz etapu planowania i realizacji badania konieczne jest

1 S. Pabis, Metodologia i metody nauk empirycznych, Warszawa 1985, s. 85. 
dokonanie przeglądu źródeł informacji istotnych dla problematyki pracy. Christopher Charles Parker i Raymond Victor Turley wskazują cztery rodzaje źródeł informacji ${ }^{2} \mathrm{tj}$. ludzi, organizacje i instytucje, literatur przedmiotu oraz służby informacyjne $e^{3}$. Wśród źródeł wykorzystywanych w badaniach postaw politycznych młodzieży szczególnie istotne są dostępne studia empiryczne czy raporty z badań. Na ich postawie można wyróżnić następujące nastawienia wobec polityki występujące w badanej grupie wiekowej:

1. Poziom zainteresowania polityką w grupie młodych wyborców jest znikomy i niższy niż w innych grupach społecznych - od 1989 do 2015 r., osoby w wieku 18-24 lata rzadziej niż ogót badanych odpowiadali, że ich zainteresowanie polityka jest bardzo duze (1-3\%) lub duze (4-5\%). Częściej natomiast swoje zainteresowanie ta dziedzin określali jako nikłe (25-37\%) lub żadne (16-27\%)4. Taki obraz młodych Polaków rysuje się również w moich badaniach przeprowadzonych w październiku 2019 r. Młodzi respondenci ocenili własny poziom zainteresowania polityką jako mały $(51,9 \%)$ lub bardzo mały $(38,8 \%)$. Zaledwie 8,5\% uznało go za duży lub bardzo duży ${ }^{5}$.

2. Poziom aktywności społecznej i politycznej wśród młodych jest także znikomy - w wolnym czasie młodzi Polacy w wieku 15-30 lat znacznie częściej deklarują chęć podejmowania aktywności sportowych (45\%), czy spotkań towarzyskich (40\%), niż angażowania się inicjatywy społeczne i wolontariackie $(22 \%)^{6}$. Z kolei zainteresowanie członkostwem w organizacjach politycznych wśród młodych wynosi zaledwie 1\%7. Młodzi są krytyczni wobec własnej grupy społecznej, oceniając zaangażowanie grupy rówieśniczej w życie polityczne jako małe $(46,0 \%)$ lub bardzo małe $(17,2 \%)^{8}$.

3. Młodzi krytycznie oceniają polityków i życie polityczne - z przeprowadzonych badań wynika, że młodych Polaków, mimo że silnie zróż-

2 G.C. Parkey, R.V. Turley, Information Sources in Science and Technology. A practical guide to traditional and online use, Butterworth-Heindemann, Londyn 1986.

3 Por. także: L.J. Anthony (red.), Information Sources in Energy Technology, Butterworths, Londyn 1988, s. 75.

4 W. Kazanecki, Zainteresowanie polityka i poglady polityczne w latach 1989-2015. Deklaracje ludzi młodych na tle ogótu badanych, Warszawa: CBOS 2015, s. 4.

5 A. Kądziela, Preferencje polityczne młodych Polaków w 2019 roku, «Studia Politologiczne» 2020, vol. 55, s. 329.

6 J. Przewłocka, Zaangażowanie społeczne Polaków w roku 2010: Wolontariat, filantropia, 1\%. Raport z badań, Stowarzyszenie Klon/Jawor, Warszawa 2011.

7 Młodzież 2010, CBOS, Warszawa 2011, s. 103.

8 A. Kądziela, Preferencje polityczne młodych Polaków..., s. 329. 
nicowanych w poglądach politycznych, łączy postrzeganie polityków i życia politycznego. To właśnie negatywny obraz życia politycznego jest wymieniany jako główny powód (32,9\% wskazań) braku zaangażowania młodych Polaków w politykę. Tak krytyczne postrzeganie życia politycznego wynika z postrzegania polityków, których pracę młodzi Polacy zgodnie oceniają raczej negatywne $(40,2 \%)$ i zdecydowanie negatywne (23,3\%). Jedynie 7,3\% wskazań dotyczyła zdecydowanie pozytywnej oceny i $28,1 \%$ umiarkowanie pozytywnej9.

4. W wyborach prezydenckich, które odbyły się w 2020 r. można było zaobserwować skokowy wzrost partycypacji wyborczej młodych Polaków, którego potwierdzeniem są dane badań exit poll realizowanych w trakcie wyborów na zlecenie TVP, TVN24, Polsat News ${ }^{10}$. W 2019 r. swój głos w wyborach do Parlamentu Europejskiego oddało zaledwie 27,6\% osób w wieku od 18 do 29 roku życia. W wyborach do Sejmu i Senatu w 2019 r. frekwencja w tej grupie wyborczej wyniosła 46,4\%. To wyniki odpowiednio niższe o 18,1 p.p. i 15,3 p.p. w stosunku do odnotowanego odsetka wśród ogółu wyborców. Pozytywna zmiana w grupie najmłodszych wyborców dała się zaobserwować w wyborach prezydenckich w 2020 r. W I turze z czynnego prawa wyborczego skorzystało aż 62,3\% uprawnionych do głosowania w wieku 18-29 lat. Był to wynik zaledwie o 0,6 p.p. niższy od frekwencji wśród wszystkich wyborców. W II turze do urn wyborczych poszło 67,2\% młodych. To wynik o 1,7 p.p. niższy od tego, który odnotowany został w całej populacji. W tym kontekście warto zaznaczyć, że mobilizacja wyborcza osób młodych miała znaczący wpływ na wynik wyborów i niewielką różnicę głosów między kandydatami w II turze wyborów. To grupa wyborców, w której wzrost frekwencji w 2020 r. względem wcześniejszych wyborów był proporcjonalnie najwyższy.

\section{Poglądy polityczne i preferencje wyborcze młodzieży w Polsce}

W kontekście analizy postaw politycznych młodzieży warto podjać próbę scharakteryzowania rzeczywistych poglądów i preferencji polityczne młodzieży. W świetle dostępnych badań, wbrew powszechnej opinii, nie można jednoznacznie określić dominujących poglądów politycznych wśród młodych Polaków. Z realizowanych w latach 1995-2018

9 Tamże, s. 333.

10 Źródło: tvn24.pl na podstawie danych Ipsos Polska. 
badań CBOS wynika, że poglądy polityczne i postawy osób w wieku od 18 do 24 lat ulegały umiarkowanym przeobrażeniom. Warto jednak zaznaczyć, że prawie $2 / 3$ nie potrafiło określić swoich poglądów na osi lewica - centrum prawica. Do 2015 r. wśród młodych osób, deklarujących swoje poglądy, największą grupę stanowiły osoby o poglądach centrowych (28-38\%). W roku 2015 r. po raz pierwszy deklaracje o poglądach prawicowych (32\%) przewyższyły deklaracje o poglądach centrowych (31\%). Poglądy prawicowe dominowały w tej grupie społecznej do połowy roku 2017 r., gdy odnotowano spadek deklaracji poglądów prawicowych do 28\%. Wówczas poglądy centrowe deklarowało $28 \%$ osób młodych ${ }^{11}$. Poglądy lewicowe w 2017 r. deklarowało zaledwie 14\% osób w wieku 18-24 lata. W zrealizowanym przez CBOS w październiku 2018 r. badaniu widoczna jest kontynuacja tego trendu - poglądy prawicowe zadeklarowało w nim 15\% respondentów, centrowe - 9\%, a lewicowe - 12\%. Aż 64\% wskazań dotyczyło niesprecyzowanych poglądów ${ }^{12}$.

Niezmiennie największą grupę osób w największym stopniu zainteresowanych polityką stanowią osoby o poglądach prawicowych (np. w $2016 \mathrm{r}$. było to aż 48\%). Uważnie lub dość uważnie to, co dzieje się w polityce śledzi zaledwie co czwarta osoba o poglądach centrowych i co piąta o poglądach lewicowych. Najwięcej osób wyrażających nikłe, niewielkie zainteresowanie polityką jest wśród osób o poglądach centrowych. Warto zauważyć, że osoby o niesprecyzowanych poglądach politycznych nie wyrażają żadnego zainteresowania polityką (aż 62\% osób).

Jeśli chodzi o nastawienie do Unii Europejskiej, to dominuje pozytywna ocena integracji Polski z Unia - blisko połowa badanych uczniów ocenia, że integracja przynosi więcej korzyści niż strat, i jest to najwięcej $w$ historii naszych badan ${ }^{13}$.

Jak zatem deklarowane poglądy polityczne przełożyły się na faktyczne poparcie w wyborach. Na podstawie wyników badań Ipsos realizowanych na zlecenie stacji telewizyjnych TVP, TVN24, Polsat News możemy dokonać próby oceny czy deklarowane poglądy polityczne młodych Polaków korespondują z ich faktycznymi wyborami.

W 2015 r. w pierwszej turze wyborów prezydenckich wśród wyborców w wieku 18-29 lat najwyższe poparcie otrzymał Paweł Kukiz (41,1\%). Kolejne miejsca zajęli: Andrzej Duda (20,7\%), Bronisław Komorowski $(13,8 \%)$ i Janusz Korwin-Mikke $(13,6 \%)$. W II turze Andrzej Duda

\footnotetext{
11 Czy młodzi Polacy sa prawicowi?, CBOS, Warszawa 2017.

12 Młodzież 2018, CBOS, Warszawa 2019.

13 Tamże, s. 12.
} 
otrzymał 59,9\%, zaś Bronisław Komorowski 40,1\%. Mając na uwadze fakt, że zarówno Paweł Kukiz, Andrzej Duda, jak i Janusz Korwin-Mikke utożsamiali się z szeroko rozumianą "prawicą" - wyniki wyborów prezydenckich w 2015 r. należy uznać za potwierdzenie wyników wcześniej omawianych badań, wskazujących na dominujące w latach 2015-2017 prawicowe postawy wśród młodych Polaków. Aż 75,4\% z głosujących młodych w 2015 r. oddało głos na trzech kandydatów prawicowych. W wyborach parlamentarnych w 2015 r. rysował się podobny portret polityczny polskiej młodzieży. Najwyższe poparcie odnotowały kolejno: Prawo i Sprawiedliwość (26,6\%), Kukiz '15 (20,6\%), KORWiN (16,8\%), Platforma Obywatelska (14,4\%), Nowoczesna Ryszarda Petru (7,8\%). Dla kolejnych ugrupowań poparcie to było poniżej 5\%. Jeśli trzy pierwsze ugrupowania uznamy za prawicowe, to poparcie dla nich w grupie najmłodszych wyborców wyniosło aż 64\%.

W 2019 r. w wyborach parlamentarnych wśród wyborców do 29 roku życia najwyższe poparcie odnotowały: Prawo i Sprawiedliwość (26,3\%), Koalicja Obywatelska PO .N i PL Zieloni (24,3\%), Konfederacja Wolność i Niepodległość (19,7\%), Sojusz Lewicy Demokratycznej (18,4\%), Polskie Stronnictwo Ludowe (9,7\%). Suma głosów oddanych na ugrupowania prawicowe tj. Prawo i Sprawiedliwość i Konfederację wyniosła 46\%. Niższy o 18 p.p. odsetek oddanych głosów na ugrupowania prawicowe względem roku 2015 zwiastował zmiany w preferencjach politycznych młodych Polaków. Zwiastowały to badania postaw, a udowodnił wynik wyborów prezydenckich w 2020 r. W I turze 23,8\% młodych Polaków oddało głos na Rafała Trzaskowskiego, 23,0\% na Krzysztofa Bosaka, 22,3\% na Szymona Hołownię, 19,3\% na Andrzeja Dudę, 7,2\% na Roberta Biedronia. W II turze kandydat Koalicji Obywatelskiej otrzymał aż 64,4\% głosów młodych, a urzędujący wówczas prezydent 35,6\%. Suma głosów, które młode osoby oddały na kandydatów prawicowych w 2020 r. (za których uznajemy Andrzeja Dudę oraz Krzysztofa Bosaka) wyniosła 42,3\% i była o 33,1 p.p. niższa od tych, które oddano na kandydatów prawicowych w wyborach prezydenckich w $2015 \mathrm{r}$.

W kontekście analizy postaw politycznych warto podkreślić, że z badań CBOS wynika, że w 2018 r., odnotowano najwyższy od 1998 roku odsetek badanych, którzy, co prawda, nie potrafia wśród istniejących $w$ Polsce partii badź ugrupowań politycznych wskazać takiego, które im się podoba, ale nie twierdza jednoznacznie, że takiej partii lub takiego ugrupowania nie $\mathrm{ma}^{14}$.

14 Tamże, s. 119. 


\section{Badania charakteryzujące postawy polityczne młodzieży w Polsce}

Mimo że preferencje polityczne młodych Polaków nie były po $1989 \mathrm{r}$. obiektem zainteresowania wielu badaczy, to warto jednak poświęcić uwagę omówieniu metodologii dostępnych badań. Sukcesywnie, nie tylko w latach wyborczych, organizowane są badania młodzieży. Do nich należy m.in. realizowana przez Centrum Badania Opinii Społecznej seria badań poświęconych młodzieży. CBOS prowadził badania ze zmienna częstościa od roku 1990, a w XXI wieku w latach 2003, 2008, 2010, 2013, 2016 i wreszcie $w 2018$ roku ${ }^{15}$. Badania realizowane były m.in. we współpracy z Instytutem Psychiatrii i Neurologii, a także z Krajowym Biurem ds. Przeciwdziałania Narkomanii. Zgodnie z informacją przedstawicieli CBOS, w badaniach zachowana jest podobna (uzupełniana o aktualne problemy) struktura kwestionariusza badawczego, umożliwiająca dokonanie analizy porównawczej. Oprócz kwestii związanych z domem rodzinnym, warunkami materialnymi, relacjami szkolnymi, aspiracjami i planami życiowymi, badania CBOS poświęcone są również problematyce aktywności obywatelskiej i poglądom na kwestie społeczno-polityczne. I tak na przykład w 43. numerze „Opinii i diagnoz” przedstawione zostały wnioski z badania sfinansowanego przez Krajowe Biuro ds. Przeciwdziałania Narkomanii i przeprowadzonego przez Fundację Centrum Badania Opinii Społecznej. Przeprowadzone w dniach 1-30 października 2018 r. badanie pt. „Konsumpcja substancji psychoaktywnych przez młodzież - Młodzież 2018” pozwala na zarysowanie portretu młodzieży - także ich postaw politycznych. W części poświęconej metodologii badania, jego autorzy informują, że zostało ono przeprowadzone metodą audytoryjną na ogólnopolskiej losowej próbie 1609 uczniów 80 szkół ponadgimnazjalnych w 69 miejscowościach ${ }^{16}$. Podczas projektowania badania podjęto decyzję o proporcjonalnym podziale uczniów na uczniów szkół państwowych i prywatnych, a także wykorzystaniu Systemu Informacji Oświatowej jako operatu losowania. Etap doboru próby polegał na realizacji zadania losowania szkół według ich rodzaju i geolokalizacji, a także losowym doborze założonych pierwotnie oddziałów, w których znajdowali się uczestnicy badania.

Obok badań Fundacji CBOS istotne miejsce wśród badań postaw politycznych młodzieży zajmuje organizowany przez Fundację Centrum Edukacji Obywatelskiej projekt „Młodzi głosują”. CEO od 1995 r. reali-

15 Młodzież 2018, CBOS, Warszawa 2019, s. 7.

16 Tamże, s. 17. 
zuje ogólnopolski program badawczy wśród uczniów szkół gimnazjalnych i ponadgimnazjalnych. Metodologia projektu zakłada przeprowadzenie badania na wzór wyborów. Oprócz walorów edukacyjnych i profrekwencyjnych, projekt ma także walor poznawczy dla potencjalnych badaczy i nie tylko. Analiza wyników badań Centrum Edukacji Obywatelskiej może dostarczyć ważnych wniosków, dotyczących postaw i preferencji politycznych uczniów szkół gimnazjalnych i ponadgimnazjalnych. Wyniki powinny być przedmiotem analizy politologów, socjologów, a także przedstawicieli mediów i polityki, którzy adresują swoje komunikaty do młodego pokolenia. Mając na uwadze fakt, że zdecydowana większość badanych uczniów, w momencie badania nie posiada jeszcze czynnego prawa wyborczego, szczególnie interesujące powinny być badania lat wcześniejszych. I tak, wyniki badań z roku 2015 powinny znaleźć się w centrum zainteresowania sztabów wyborczych, budujących strategię komunikacyjną wśród młodych wyborców w 2020 r. W ciągu 5 kolejnych lat, badani uczniowie zdobywali bowiem prawo do głosowania. W badaniu CEO przed wyborami prezydenckimi, które odbyły się w maju 2015 r., wzięło udział 195 tys. uczniów z 1415 szkół. Największą popularnością wśród przyszłych wyborców cieszył się Janusz Korwin-Mikke ${ }^{17}$, który w I turze otrzymałby aż 28,99\% głosów. Na drugim miejscu z wynikiem 18,87\% znalazł się wówczas urzędujący Prezydent RP, Bronisław Komorowski. Tuż za nim, z wynikiem 18,02\% uplasował się kandydat Prawa i Sprawiedliwości Andrzej Duda. Dobry wynik uzyskał kandydujący po raz pierwszy, Paweł Kukiz (13,4\%). Co dziesiąty uczeń oddałby swój głos na kandydatkę Sojuszu Lewicy Demokratycznej. Pozostali kandydaci uzyskaliby wyniki poniżej 5\%: Janusz Palikot (4,73\%), Marian Kowalski (1,77\%), Adam Jarubas (1,46\%), Grzegorz Braun (1,30\%), Jacek Wilk (0,87\%), Paweł Tanajno (0,69\%). Wyniki te, w szczególności w kontekście wyników wyborów prezydenckich, które odbyły się w 2020 r., stanowić mogą pewne wskazówki dla uzasadnienia niskiego poparcia dla Andrzeja Dudy (zaledwie 35,6\%) wśród wyborców od 18. do 29. roku życia i znacznie wyższego, bo aż 64,4\%, dla Rafała Trzaskowskiego.

Pozostałe projekty badawcze stanowiące odpowiedź na istotną lukę badawczą, związaną z brakiem ilościowych, istotnych statystycznie badań postaw i preferencji politycznych młodzieży stanowią cenne uzupełnienie

17 J. Witkowski, Wyniki młodzieżowych wyborów parlamentarnych 2015. Młodzi głosuja, https:// www.wrotapodlasia.pl/pl/edukacja/edukacja_nauka/wyniki-mlodziezowych-wyborow-mlodzi-glosuja.html (7.04.2021). 
powyższych badań. W 2019 r. na zlecenie Fundacji Konrada Adenauera przeprowadzony został projekt badawczy „Determinanty partycypacji wyborczej młodych Polaków w 2019 r.”. Dane zebrane zostały metodą wywiadów telefonicznych ze wspomaganiem komputerowym (CATI) na reprezentatywnej, ogólnopolskiej grupie pełnoletnich mieszkańców Polski do 30. roku życia. W dniach 5-23 września 2019 r. Centrum Badań Marketingowych INDICATOR zrealizowało je na zlecenie Fundacji Konrada Adenauera w Polsce ( $\mathrm{N}=1200$ wywiadów).

Chęć uzupełnienia luki badawczej rodzi konieczność rzetelnego zaprojektowania ogólnopolskiego badania postaw politycznych młodzieży tj. szczegółowego harmonogramu, dostosowanego do problematyki badawczej. Każde badanie empiryczne wymaga opracowania szczegółowego harmonogramu, uwzględniającego cele, sposób realizacji i interpretacji jego wyników. Opis etapów projektowania badań empirycznych należałoby zacząć od zdefiniowania roli człowieka jako twórcy i przedmiotu badań ${ }^{18}$. Każda z tych ról wpływa na określony katalog pożądanych zachowań. Rola kierownika projektu badawczego nakłada na niego szereg obowiązków związanych z opracowaniem koncepcji i harmonogramu badania. Przesłanką do rozpoczęcia procesu badawczego jest zdiagnozowanie problemu badawczego i wskazanie przyczyn doniosłości danego problemu np. dlaczego niski poziom partycypacji politycznej młodych Polaków jest ważny dla społecznej praktyki lub legitymizacji władzy? Zazwyczaj diagnoza ta wynika z obserwacji, subiektywnych odczuć badacza, jego zaciekawienia lub po prostu interesujących przesłanek w formie danych publicznych. Na początkowym etapie wskazane jest zebranie i usystematyzowanie literatury przedmiotu. Efektywne przeprowadzenie tego procesu umożliwiają różnego typu katalogi, które mogą być ułożone alfabetycznie lub rzeczowo (każdej wyróżnionej dziedzinie wiedzy przypisywana jest odpowiednia cyfra). Istnieja specjalne katalogi (tezaurusy) stów kluczowych, którymi warto postugiwać się szczególnie wtedy, gdy korzystamy odpłatnie z baz danych ${ }^{19}$. Równolegle do lektury lub przeglądu opublikowanych prac, warto pamiętać o gromadzeniu danych. Dobrą praktyką jest sporządzanie notatek w trakcie poszukiwań bibliograficznych, uwzględniających zarówno dane o autorze i publikacji, jak i najistotniejsze informacje. Sumiennie przeprowadzona kwerenda powinna pozwolić na otrzymanie odpowiedzi na pytania o aktualny stan badań, ich rezultat i ewentualną konieczność ich uzupełnienia. Jeśli zdaniem badacza stan

18 S. Pabis, Metodologia i metody nauk empirycznych, Warszawa 1985, s. 247.

19 R. Błażejewski, Wstęp do badań empirycznych, Poznań 1999, s. 25. 
badań nie pozwala na dostateczne wyjaśnienie zarysowanego problemu badawczego, przechodzi on do kolejnego kroku, w którym określa kategorię teoretyczną badania i przedmiot badań, uszczegóławiając tym samym zarysowany wcześniej problem badawczy. $\mathrm{Na}$ tej podstawie możliwe jest utworzenie zespołu badawczego, zdefiniowanie konkretnego celu badań, a także skonstruowanie pytań i hipotez badawczych. W kolejnym etapie pozwoli to badaczowi na dobór materiałów źródłowych oraz określenie metodyki badania tj. sposobu przeprowadzenia badania w określonym paradygmacie, określonej pespektywie badawczej. Wybór ten determinować będzie metody i techniki badawcze, które z kolei będą miały istotne znaczenie dla stworzenia odpowiedniego narzędzia badawczego, sposobu gromadzenia danych i ich analizowania. Taki układ uporządkowanych czynności pozwala na weryfikację założonych pierwotnie hipotez badawczych, opracowanie wniosków rekomendacji i być może zaprojektowanie nowej teorii. Jak słusznie zaznacza prof. Stanisław Pabis, etap końcowy badań, choć należy do najistotniejszych, często jest przez badaczy lekceważony. Formułowane na tym etapie zdania mogą być poprawne, powszechnie akceptowalne, lecz w żaden sposób niespełniające utylitarnego charakteru nauki, tym samym nie przyczyniając się do jej rozwoju. Dlatego wnioskami pracy będacej badaniem doświadczalnym powinny być tylko takie zdania, które zawieraja nowe informacje uzyskane w wyniku danego badania ${ }^{20}$. Pomocne w tym zakresie mogą być sformułowane wcześniej założenia i hipotezy badawcze, które na ostatnim etapie badania podlegają weryfikacji, tj. potwierdzeniu lub obaleniu.

I tak, dostrzeżenie w wyniku przeglądu literatury przedmiotu istotnej luki badawczej związanej z brakiem ogólnopolskich badań ilościowych nad postawami politycznymi młodych Polaków, a także podnoszony w debacie publicznej problem bierności politycznej młodzieży stanowił impuls realizacji projektu badawczego „Determinanty partycypacji wyborczej młodych Polaków w 2019 r.”. Badanie postaw politycznych młodzieży wymaga nie tylko rzetelnego podejścia metodologicznego i przeglądu literatury przedmiotu, ale także wyróżnienia celu badania, konceptualizacji i operacjonalizacji kluczowych pojęć, doboru próby. Tak przeprowadzony pierwszy etap umożliwia przystąpienie do tworzenia narzędzia - kwestionariusza badawczego. To z stanowi punkt wyjścia do przeprowadzenia badania. Dopiero odpowiednio przetworzone dane mogą zostać poddane analizie. Na podstawie przeprowadzonej analizy formułowane są wnioski.

20 Tamże, s. 248. 
W każdym z tych etapów istotnym elementem, o którym warto pamiętać w szczególności w kontekście badań nad młodzieżą, są kwestie etyczne.

\section{Cel badań}

Obok określenia planu i harmonogramu projektu badawczego, warunkiem do rozpoczęcia projektowania badania jest określenie jego celu naukowego. W tym miejscu badacz określa przedmiot badania, problem badawczy, granice pola badawczego, a także pytania i hipotezy badaw$\mathrm{cze}^{21}$. Na tym etapie warto poddać refleksji znaczenie wyników projektu badawczego dla rozwoju nauki. Celem empirycznych badań naukowych jest formułowanie naukowo uzasadnionych $i$ empirycznie sprawdzalnych wyjaśnień obserwowanych faktów empirycznych ${ }^{22}$. W kontekście niniejszej pracy interesować będzie nas sposób formułowania faktów, związanych z problematyką postaw politycznych młodziė̇y. Szeroki zakres tematyczny umożliwia ustalanie prawd dotyczących zmiennych determinujących występowanie określonych postaw wśród młodych Polaków. Zasadniczym celem dostępnych badań jest określenie postaw politycznych młodych Polaków i próba odpowiedzi na pytania o ich przyczyny. Tak zdefiniowany cel badawczy rodzi konieczność sformułowania adekwatnych pytań i hipotez badawczych. Założony cel osiągnięty zostaje w sytuacji, w której hipotezy zostaną zweryfikowane - przyjęte lub odrzucone. Wyjaśnienie badanego zjawiska lub faktu jest możliwe jedynie na gruncie naukowego, podlegającego weryfikacji uzasadnienia. Teorie bowiem $i$ hipotezy, które nie moga być sprawdzone nie maja naukowej wartości ${ }^{23}$. W zależności od przyjętej metody tworzenia teorii, dedukcyjnej bądź indukcyjnej, wnioski z badań będą miały charakter pewny lub niepewny. Mając na uwadze to, że punktem wyjścia do formułowania teorii jest zbiór zdań obserwacyjnych, wynikających z jednostkowych pomiarów czynników wpływających na postawy młodych Polaków, ogólne wnioskowanie będzie miało zazwyczaj charakter indukcyjny. Spełnienie celu bezpośredniego, jakim jest opis postaw politycznych młodzieży, jak i naukowe wyjaśnienie obserwowanego zjawiska przyczynia się pośrednio do realizacji dodatkowych, niezdefiniowanych wcześniej celów, wśród których należy wyróżnić m.in. usystematyzowanie

21 J. Wiśniewska, R. Backer (red.), Metodologia badan politologicznych, Warszawa 2016, s. $12-13$.

22 S. Pabis, Metodologia i metody..., s. 132.

23 Tamże, s. 133. 
wiedzy, zdiagnozowanie związków między różnymi zmiennymi, a także wyróżnienie ewentualnych braków i luk badawczych, na podstawie których możliwe jest konstruowanie nowych kierunków badawczych. Obok funkcji poznawczych, warto wyróżnić funkcje utylitarne zrealizowanych badań, do których należy m.in. możliwość przewidywania zmian, prognozowania wystąpienia określonych zdarzeń, ale także kształtowanie opinii na temat badanego problemu, opracowanie rekomendacji i wywieranie wpływu na konkretne zmiany w badanym obszarze.

Celem projektu badawczego „Determinanty partycypacji wyborczej młodych Polaków w 2019 r.” było uzupełnienie wyróżnionej na wcześniejszym etapie luki badawczej poprzez realizację badania na ogólnopolskiej reprezentatywnej grupie młodych Polaków, nakreślenie stosunku młodzieży do problemów społeczno-politycznych, a także wyróżnienie czynników wpływających określone postawy młodzieży. Analiza końcowa wyników przeprowadzonego badania i weryfikacja hipotez pozwoliła na wyprowadzenie wniosków i nakreślenie portretu postaw politycznych najmłodszej grupy wyborców.

\section{Konceptualizacja i operacjonalizacja pojęć}

Procesy konceptualizacji i operacjonalizacji są ze sobą ściśle związane. Proces, $w$ toku którego określamy, co mamy na myśli używając danego terminu $w$ badaniach nazywamy konceptualizacją ${ }^{24}$. Z punktu widzenia badań empirycznych dotyczących postaw politycznych młodzieży istotne jest zdefiniowanie i wyjaśnienie pojęć istotnych dla przeprowadzenia badania i zrozumienia jego wyników tj. młodzież i postawy polityczne. W obu pojęciach warto wskazać typologię, wskazując na zróżnicowanie młodzieży (np. szkolna, akademicka, wchodząca w dorosłe życie), a także postaw politycznych (np. aktywność - bierność, prawicowość - lewicowość, liberalizm - socjalizm). Badacz w tym kroku ostatecznie doprecyzowuje granice pola badawczego, czyli konkretyzuje przedmiot badan oraz podejmowany problem badawczy. Dopiero na tej podstawie formutuje główne i szczegótowe hipotezy badawcze 25 .

Konceptualizacja pojęcia postawa polityczna jest o tyle nieproblematyczna, że rodzi jedynie konieczność dokonania przeglądu literatury

24 E. Babbie, Badania społeczne w praktyce, Warszawa 2004, s. 144.

25 J.J. Buttolph, H.T. Reynolds, J.D. Mycoff, Metody badawcze w naukach politycznych, Warszawa 2010, s. 85-94. 
politologicznej i socjologicznej, której przedmiotem będzie stosunek społeczeństwa do polityki, jej podmiotów, instytucji i idei politycznych. Postawy polityczne kształtuja sie $w$ procesie socjalizacji politycznej. [...] Rodzina, szkoła, media, a $w$ niektórych krajach także instytucje religijne, to podmioty odgrywajace zasadnicza role $w$ procesie socjalizacji politycznej ${ }^{26}$. To podejście jest cenne dla badacza w sytuacji, w której przedmiotem badania jest rola i wpływ wyżej wymienionych podmiotów na postawy polityczne. W odniesieniu do problematyki niniejszego opracowania ciekawą definicją postawy politycznej, która umożliwi operacjonalizację pojęć i opracowanie kwestionariusza badawczego jest definicja zaproponowana przez prof. Bogdana Wojcieszke. Wyróżnił on trzy komponenty postawy politycznej: poznawczy, emocjonalno-oceniający i behawioralny. Pierwszy rodzaj określa całokształt wiedzy, dotyczący systemu politycznego. Drugi obejmuje zestaw uczuć w stosunku do zjawisk politycznych, a komponent behawioralny jest tożsamy z gotowością lub jej brakiem do podjęcia aktywności politycznej27.

Znacznie bardziej problematyczne jest dokonanie konceptualizacji pojęcia młodziė̇. Brak jednoznacznej definicji młodzieży stawia przed badaczem konieczność pokazania szerokiego spektrum definicyjnego, wyboru najwłaściwszej definicji lub zaproponowania własnej, odpowiadającej potrzebom badania. Niezwykle ważny w tym procesie jest przegląd literatury o podobnej problematyce, a także kontekst badania. Badając postawy polityczne młodych Polaków badacz może uczynić przedmiotem analizy młodzież w wieku szkolnym tj. uczniów szkół gimnazjalnych i ponadgimnazjalnych (tak jak uczyniła to Fundacja Centrum Edukacji Obywatelskiej) lub uczniów szkół ponadgimnazjalnych (wzorem Fundacji Centrum Badania Opinii Społecznej). W ramach projektu badawczego „Determinanty partycypacji wyborczej młodych Polaków w 2019 r.” zaproponowano własną grupę badanych tj. najmłodszych wyborców, posiadających czynne prawo wyborcze do 30. roku życia ${ }^{28}$. O ile dolna granica wieku na poziomie 18 lat wynika z obiektywnych, konstytucyjnych przesłanek, to już decyzja o ustaleniu górnej granicy na poziomie 30 lat motywowana było koniecznością dokonania subiektywnego wyboru umownego momentu wejścia w dorosłość. Podłożem merytorycznym decyzji był przegląd danych statystycznych (np. Głównego Urzędu Sta-

26 P. Pawełczyk, K. Churska-Nowak, B. Jankowiak, Struktura i uwarunkowania afektywnego komponentu postaw politycznych studentów, «Przegląd Polityczny» 2018, s. 7.

27 B. Wojciszke, Postawy $i$ ich zmiana, «Psychologia» 2005, vol. 3, s. 33-34.

28 Konstytucja Rzeczypospolitej Polskiej z dnia 2 kwietnia 1997 r. (Dz.U. Nr 78, poz. 483 ze zm.), art. 62 . 
tystycznego) oraz raportów (m.in. Polskiej Agencji Rozwoju Przedsiębiorczości), które wskazują podobną górną granicę wieku młodzieży.

Skonkretyzowanie problemu badawczego w procesie konceptualizacji umożliwia przejście do kolejnego kroku, jakim jest operacjonalizacja, czyli przyporządkowanie stworzonej wcześniej siatce pojęciowej mierzalnych wskaźników ${ }^{29}$. Opracowanie mierzalnych kryteriów umożliwi na dalszych etapach badania dokonanie pomiaru i określenie poziomu wiedzy i ocen na temat polityki, stosunku do zjawisk politycznych oraz gotowości do działania. To z kolei będzie elementem niezbędnym do weryfikacji hipotez badawczych.

\section{Hipotezy badawcze}

Naukowiec - teoretyk czy eksperymentator - formutuje zdania lub systemy zdań, które sprawdza krok po kroku. W szczególności na polu nauk empirycznych konstruuje on hipotezy systemy teorii $i$ sprawdza je doświadczalnie poprzez obserwacje $i$ eksperyment ${ }^{30}$. Aby osiaggnąć cel badań i dokonać weryfikacji hipotez istotne jest określenie zmiennych zależnych i niezależnych oraz wskaźników, umożliwiających badanie zależności i siły między zmiennymi. Zmienna zależna (wyjaśniana) musi być zmienna mierzona co najmniej na poziomie porządkowym. Zmienna niezależna (wyjaśniajaca) może być mierzona na dowolnej skali od nominalnej do ilorazowej, musi jednak przyjmować co najmniej dwie wartości ${ }^{31}$. Wśród zmiennych niezależnych wyróżnić można np. wiek, płeć, wykształcenie, miejsce zamieszkania. Z kolei zmienna zależna będzie tłumaczyła badane przez nas zjawisko. To np. poziom zainteresowania polityką lub uczestnictwa w życiu politycznym (jego rodzaj i częstotliwość), rola i postrzeganie polityki jako narzędzie do zaspokajania potrzeb, środowisko rodzinne i lokalne oraz warunki materialne.

Z kolei za zdanie, będące hipotezą należy uznać zdanie, będące przypuszczeniem, którego prawdziwość można zweryfikować przy pomocy zdań obserwacyjnych. Hipoteza wyjaśniająca zatem to zdanie empiryczne, mogace być sprawdzone logicznie przy pomocy zdań pewnej teorii empirycznej $i$ mogace być sprawdzone empirycznie przy pomocy zdań obserwacyjnych,

29 J. Wiśniewska, R. Backer (red.), Metodologia badań politologicznych, Warszawa 2016, s. 19.

30 K.R. Popper, Logika odkrycia naukowego, Warszawa 1977, s. 29.

31 D. Mider, A. Marcinkowska, Analiza danych ilościowych. Praktyczne wprowadzenie z wykorzystaniem programu GNU PSPP, Warszawa 2013, s. 324. 
którego treść przedstawia wyjaśnienie jakiegoś faktu empirycznego - systemu, zjawiska lub zdarzenia ${ }^{32}$. Tak rozumiane hipotezy pozwalają na realizację naukowego celu, jakim jest empiryczne wyjaśnienie danych systemów, zjawisk, zdarzeń oraz tworzenie lub doskonalenie teorii.

W kontekście badań, dotyczących młodych Polaków można wysnuć przykładowe hipotezy stanowiące, że prawdopodobieństwo niskiego uczestnictwo w życiu politycznych jest uwarunkowane czynnikami socjodemograficznymi, sytuacją ekonomiczną, negatywnym postrzeganiem życia politycznego przez młodych Polaków. Na podstawie powyższej hipotezy można postawić także przykładowe hipotezy szczegółowe:

a) przyczyną małego zainteresowania polityką wśród młodych jest negatywny obraz życia politycznego;

b) niewielki poziom zainteresowania polityką wpływa na bierność polityczną młodych Polaków;

c) postawy polityczne młodych Polaków warunkowane są poziomem wykształcenia;

d) zakłada się, że brak sprecyzowanych poglądów wpływa na niski poziom uczestnictwa młodych Polaków w wyborach.

Jeśli badacz zdefiniował już cel badania, przeprowadził proces konceptualizacji i operacjonalizacji kluczowych pojęć, a także określił pytania oraz hipotezy badawcze, istotne dla dalszej części badania jest opracowanie kwestionariusza badawczego i dobór próby.

\section{Dobór próby}

Próba to nic innego jak część populacji, biorąca udział w badaniu. Przedmiot zainteresowania badacza uzależniony jest od przyjętego założenia definicyjnego, określającego np. ramy wiekowe dla badanej grupy. W literaturze przedmiotu wyróżnione zostały dwa rodzaje doboru próby tj. probabilistyczny i nieprobabilistyczny. Aby zapewnić reprezentatywność doboru, tj. możliwość wnioskowania z próby na ogół badanej populacji konieczne jest zastosowanie doboru probabilistycznego. Konieczne jest jednak określenie operatu losowania, czyli listy wszystkich elementów badanej populacji ${ }^{33}$. Wtedy badacz stoi przed decyzją, czy zastosować dobór losowy prosty, systematyczny, czy warstwowy. Pierwszy z nich oznacza wylosowanie określonego procentu do stworzenia próby. Dobór losowy

32 S. Pabis, Metodologia i metody..., s. 132.

33 J. Wiśniewska, R. Backer (red.), Metodologia badań politologicznych..., s. 177. 
systematyczny oznacza wylosowanie jednostek do próby z określoną częstotliwością. Trzeci rodzaj wprowadza podział populacji na warstwy, umożliwiając $\mathrm{w}$ drodze losowania proporcjonalny udział każdej z nich próbie. Minimalne liczebności określa się $w$ literaturze przedmiotu na 30 lub 120 jednostek analizy ${ }^{34}$. Sytuacja, w której badacz nie posiada dostępu do operatu losowania, powoduje konieczność skorzystania z doboru nieprobabilistycznego, który uniemożliwia wnioskowanie z próby na populację. Rodzi to konieczność dokonania np. doboru celowego, polegającego na wybraniu do próby określonych elementów, posiadających istotną z punktu widzenia badania cechę.

Aby zapewnić możliwości wnioskowania z próby na populację, badanie „Determinanty partycypacji wyborczej młodych Polaków w 2019 r.” przeprowadzone zostało metodą wywiadów telefonicznych wspomaganych komputerowych (CATI) na reprezentatywnej, ogólnopolskiej próbie liczącej 1200 osób (N) w wieku 18-30 lat. Próba była reprezentatywna ze względu na takie zmienne jak: płeć, wiek, województwo, wielkość miejsca zamieszkania.

\section{Tworzenie narzędzi badawczych}

Po określeniu problemu badawczego i hipotez badacz staje przed zadaniem wyboru rodzaju i stworzenia narzędzia badawczego oraz metody prowadzenia badania, tak by w najbardziej rzetelny sposób możliwe było zweryfikowanie hipotez. Wybór narzędzia badawczego i metody prowadzenia badania wpływa także na możliwość przeprowadzania danego badania wśród określonej liczby osób. Zdaniem Stefana Nowaka w przypadku nauk empirycznych przez metody rozumie sie przede wszystkim typowe $i$ powtarzalne sposoby zbierania, opracowywania, analizy $i$ interpretowania danych empirycznych, stużace do uzyskiwania maksymalnie lub optymalnie uzasadnionych odpowiedzi na stawiane $w$ danej nauce pytania ${ }^{35}$. Wybór metody badawczej wpływa na specyfikę relacji między badaczem a badanymi zjawiskami lub obiektem. Stosowanie badań ilościowych, w ramach paradygmatu neopozytywistycznego nakazuje badaczowi przyjęcie zdystansowanej pozycji, eliminującej jakąkolwiek możliwość zaangażowania - fakty społeczne analizowane są więc z pozycji zewnętrznego obserwatora. Z kolei w badaniach jakościowych, w ramach paradygmatu

34 D. Mider, A. Marcinkowska, Analiza danych ilościowych..., s. 48.

35 J. Wiśniewska, R. Backer (red.), Metodologia badań politologicznych..., s. 63. 
interpretatywnego, badacz jest zaangażowany, uwikłany w badaną rzeczywistość, będąc jednocześnie podmiotem i przedmiotem poznania. Za właściwą metodę dla badania „Determinanty partycypacji wyborczej młodych Polaków w 2019 r.” uznano metodę ilościową. Metoda ta może stanowić punkt wyjścia do poszukiwania odpowiedzi na pytania o przyczyny takiego, a nie innego stanu rzeczy. Wówczas właściwszą metodą będą metody jakościowe i np. indywidualny wywiad pogłębiony, obserwacja uczestnicząca, jakościowa analiza treści, czy analiza dyskursu. Kombinację wielu praktyk metodologicznych, w tym łączenie różnych metod badawczych, nazywamy triangulacją. Wykorzystanie wielu metod umożliwia głębsze zrozumienie badanego zjawiska, a także zapewnia zwiększenie wiarygodności uzyskanych materiałów i ich interpretacji. Podstawowym narzędziem badawczym w badaniach ilościowych, umożliwiającym gromadzenie danych jest zanonimizowany, zestandaryzowany kwestionariusz badawczy. Dzięki temu możliwe jest przeprowadzenie większej liczby wywiadów. Do typowych dla badania ilościowego metod należą wywiad bezpośredni z wykorzystaniem papierowego kwestionariusza (PAPI), wywiad bezpośredni wspomagany komputerowo (CAPI), wywiad telefoniczny wspomagany komputerowo (CATI), ankieta internetowa (CAWI).

W przeprowadzonym we wrześniu 2019 r. badaniu postaw politycznych młodzieży kwestionariusz badawczy składał się z tytułu, wprowadzenia, zestawu pytań, a także tzw. metryczki. Istotą każdego kwestionariusza badawczego są pytania. Wszystkie pytania miały charakter zamknięty. Oznacza to, że respondenci mogli wybrać odpowiedzi z tych, które zaproponował badacz. W pierwszej części ankiety pytania miały charakter ogólniejszy i dotyczyły zaangażowania społeczno-politycznego. W kolejnej części celem było sprofilowanie badanych osób. W tym celu konieczne było uzyskanie odpowiedzi, m.in. na pytania o sposób gospodarowania dochodem, miejsce pracy, zamieszkania, poglądy polityczne i wyznawane wartości. Trzecia część kwestionariusza stanowiła zasadniczą część badania i dotyczyła partycypacji wyborczej, a także poglądów na wyróżnione problemy społeczno-ekonomiczne. Ostatnia cześć, czyli metryczka, poświęcona była pytaniom dotyczącym danych socjodemograficznych (wiek, płeć, wielkość miejscowości zamieszkania, wykształcenie), które w procesie analizy i interpretacji wyników posłużyły za zmienne niezależne. 


\section{Przetwarzanie, analiza i interpretacja danych}

Dostępne oprogramowanie komputerowe umożlwiające obsługę badań pozwala nie tylko na wspomaganie prac związanych z planowaniem, przeprowadzeniem badania, ale także na rekonfigurację uzyskanych danych i analizę statystyczną. Najczęściej wykorzystywane oprogramowanie do przetwarzania danych ilościowych to m.in. STATISTICA, SPSS i darmowa alternatywa dla SPSS tj. GNU PSPP.

W celu weryfikacji wyróżnionych na wcześniejszym etapie hipotez badawczych konieczne jest przeprowadzenie testów parametrycznych (t-Studenta, analiza wariancji, korelacja r-Pearsona, analiza regresji) lub nieparametrycznych (test U Manna-Whitneya, test Kruskala-Wallisa, test niezależności chi-kwadrat, korelacja tau-b Kendalla). Do stwierdzenia, czy między wyróżnionymi zmiennymi występuje korelacja, konieczne jest określenie liczebności jednostek analizy, typu rozkładu zmiennych i przede wszystkim dobór zmiennych mierzonych na właściwym dla danego testu poziomie. Testy parametryczne pozwalają na uzyskanie dokładniejszego wyniku, wskazując nie tylko istotność i siłę zależności między zmiennymi, ale także jej kierunek. $Z$ kolei testy nieparametryczne stuża do pomiaru zwiazków dla zmiennych mierzonych na poziomach jakościowych $^{36}$. W badaniach, w których przedmiotem jest problematyka socjologiczna lub politologiczna zmienne najczęściej mierzone są na poziomie jakościowym. To implikuje konieczność zastosowania testów nieparametrycznych. I tak na przykład uzyskany wynik, przeprowadzonego w ramach analizy danych z badania „Determinanty partycypacji wyborczej młodych Polaków w 2019 r., testu niezależności chi-kwadrat Pearsona dla dwóch zmiennych tj. wiek i deklaracja udziału w wyborach parlamentarnych, jest istotny statystycznie.

$$
\chi \cdot(2, \mathrm{~N}=1200)=8,26 ; \mathrm{p} \leq 0,05
$$

Otrzymany wynik oznacza, że między wyróżnionymi zmiennymi istnieje statystycznie istotna zależność. Najmłodsi wyborcy do 24. roku życia częściej deklarują brak udziału w wyborach niż osoby w wieku 25-30 lat.

Należy pamiętać, by po uzyskaniu wyników badań i przed przejściem do szczegółowej analizy zależności między zmiennymi, sprawdzić czy każda z poddanych analizie zmiennych ma rozkład zbliżony do rozkładu normalnego. Dla stwierdzenia czy rozkład jest normalny istotne

36 D. Mider, A. Marcinkowska, Analiza danych ilościowych..., s. 200. 
są wyniki testu Kołomogorowa-Smirnowa ${ }^{37}$. W interpretacji istotne są wartości statystyki $Z$ oraz poziomu ufności $(\alpha)$. Jeśli wynik $\alpha$ jest wyższy od 0,05 to badacz może przyjąć, że rozkład danej zmiennej jest normalny i może on przystąpić do jednoczynnikowej analizy wariancji i dalszego przeprowadzania testów.

\section{Etyka w badaniach - o „Kodeksie etyki pracownika naukowego” słów kilka}

Tak jak w każdym badaniu, tak i w badaniu postaw politycznych młodzieży, istotne jest przestrzeganie zasad i postępowanie w sposób etyczny. Warto więc poświęcić fragment niniejszej pracy na refleksję nad zasadami, o których w toku tworzenia projektu badawczego każdy badacz powinien pamiętać. Arystoteles definiuje naukę przez pryzmat jej celu. Dokonując trychotomicznego podziału nauk na teoretyczne, praktyczne i pojetyczne podkreślał, że celem nauk teoretycznych jest formułowanie wiedzy dla jej samej, celem nauki praktycznej jest osiagnięcie doskonałości moralnej, zaś nauki pojetycznej wytworzenia określonych dóbr. W „Etyce nikomachejskiej” wskazuje, że celem działania jest dobro, dowodząc, że celem sztuki lekarskiej jest zdrowie, zaś przedmiotem nauki o państwie jest szczęście ${ }^{38}$. W księdze drugiej „Etyki nikomachejskiej” uzupełnia swoje rozważania o zaletach etycznych, czyli cnotach, wynikających z dobrego działania. Thomas Kuhn w „Strukturze rewolucji naukowych” analizując proces rozwoju nauki wyróżnia naprzemiennie występujące okresy nauki normalnej i rewolucji naukowej. Filozof nauki zwraca jednak uwage na niezmienne zasady i reguły obowiązujące w nauce. Zaznacza, że nauka ma charakter kumulatywny, daży do statego poszerzania zakresu i zwiększenia precyzji wiedzy naukowej39, zaś świat naukowy od nienaukowego odróżnia przede wszystkim wykorzystanie teorii i wyznaczany przez paradygmaty określony sposób organizacji pracy i prowadzenia badań. W «Filozofii nauki» Michał Heller podkreśla, że celem uprawiania nauk empirycznych jest tworzenie teorii, dzięki którym świat staje sie zrozumiaty ${ }^{40}$. Tworzenie teorii winno być więc osiaggane w sposób etyczny. Mając więc na uwadze cel

37 Tamże, s. 329.

38 Przedruk z: Arystoteles, Etyka Nikomachejska, przełożyła D. Gromska, Warszawa 1956, s. 3-345.

39 T.S. Kuhn, Struktura rewolucji naukowych, The University of Chicago Press, Chicago 1962, http://sady.up.krakow.pl/filnauk.kuhn.struktura.htm, (20.04.2020).

40 M. Heller, Filozofia nauki, Warszawa 2016. 
nauki należy zadać pytanie o sposób, w jaki zostanie on osiągnięty. Czzy definiowana poprzez teliczny charakter nauka może zachęcać naukowców do stosowania nieetycznych praktyk? Historia pełna jest przykładów praktyk, które naruszają zasady i wartości etyczne. Za najbardziej wyraziste przykłady większość z nas uznałaby m.in. przeprowadzony w 1961 r. i 1962 r. eksperyment S. Milgrama, czy stanfordzki eksperyment więzienny z $1971 \mathrm{r}$. Potępiając tak jaskrawe przykłady nieetycznego postępowania badaczy, zapominamy jednak o mniej jaskrawych sposobach łamania zasad i wartości etycznych w pracy naukowej - takich, którymi jesteśmy świadkami na co dzień. Odnoszą się one do postępowania z danymi naukowymi, procedur badawczych, ale także recenzowania i opiniowania prac naukowych, formowania młodej kadry, relacji ze społeczeństwem.

Zbiorem dobrych praktyk, a także wskazówek, dotyczących postępowania w sprawach o naruszenie zasad rzetelności w nauce jest „Kodeks etyki pracownika naukowego”. Każdy członek społeczności akademickiej powinien zapoznać się z opracowanym przez komisję do spraw etyki w nauce Polskiej Akademii Nauk i uchwalonym 1 grudnia 2016 r. przez Zgromadzenie Ogólne dokumentem. Dlaczego każdy, skoro Kodeks adresowany jest do pracowników naukowych? Dlatego, że zawarte w Kodeksie zasady są uniwersalne i odnoszą się zarówno do studentów, jak i pracowników naukowych. Kwestie dotyczące sposobu i metod prowadzenia badań, wiarygodności, obiektywizmu, niezależności, otwartości na argumenty innych naukowców, transparentności, rzetelności w ocenie, a także odwagi w obronie popartych dowodami osiągnięć nauki, powinny być bliskie wszystkim badaczom. Kodeks stanowi również cenne źródło informacji na temat postępowania z danymi naukowymi, sposobu publikacji wyników badań, recenzowania i opiniowania prac badawczych. To z kolei może stanowić swego rodzaju drogowskaz w sytuacji, w której konieczne jest rozstrzygnięcie wątpliwości badacza. Dokument reguluje też sposób postępowania w sytuacjach, w których dochodzi do fabrykowania wyników, fałszowania ich, a także popełniania plagiatów. Zawarte w „Kodeksie etyki pracownika naukowego" zasady powinny przyświecać każdemu, kto czuje się pełnoprawnym, odpowiedzialnym członkiem społeczności akademickiej. To od nas bowiem zależy, czy nauka będzie osiągała swoje cele i czy będzie je osiągała w sposób etyczny. 


\section{Bibliografia}

Anthony L.J., Information Sources in Energy Technology, Butterworths, Londyn 1988.

Babbie E., Badania spoteczne $w$ praktyce, Warszawa 2004.

Błażejewski R., Wstęp do badań empirycznych, Poznań 1999.

Kądziela A., Preferencje polityczne młodych Polaków w 2019 roku, «Studia Politologiczne» 2020, vol. 55.

Mider D., Marcinkowska A., Analiza danych ilościowych. Praktyczne wprowadzenie z wykorzystaniem programu GNU PSPP, Warszawa 2013.

Pabis S., Metodologia i metody nauk empirycznych, Warszawa 1985.

Parkey C.C., Turley R.V., Information Sources in Science and Technology. A practical guide to traditional and online use, London: Butterworth-Heindemann 1986.

Pawełczyk P., Churska-Nowak K., Jankowiak B., Struktura i uwarunkowania afektywnego komponentu postaw politycznych studentów, «Przegląd Polityczny» 2012, nr 4.

Popper K.R., Logika odkrycia naukowego, Warszawa 1977.

Przewłocka J., Zaangażowanie społeczne Polaków w roku 2010: Wolontariat, filantropia, 1\%. Raport z badan, Stowarzyszenie Klon/Jawor, Warszawa 2011.

Stańkowski B., Problemy dorastajacej młodzieży. Rodzina i szkoła w oczach nastolatków - raport $z$ badań empirycznych na Podhalu, Kraków 2005.

Szafraniec K., Młodzi 2011, Kancelaria Prezesa Rady Ministrów, Warszawa 2011.

Szymanowski T., Młodzież wobec alkoholu, Warszawa 1990.

Urbanek J., Uczestnictwo młodzieży akademickiej w kulturze, Kraków 2002.

Wiśniewska J., Backer R. (red.), Metodologia badań politologicznych, Warszawa 2016.

Wojciszke B., Postawy i ich zmiana, «Psychologia» 2005, vol. 3. 